REVISTA DE DERECHO UNED, NÚM. 8, 2011

\title{
LA INCIDENCIA DE LA ADAPTACIÓN A LA CONVENCIÓN DE LAS PERSONAS CON DISCAPACIDAD EN LOS SUPUESTOS DE DONACIÓN DE ÓRGANOS Y DE MÉDULA: LOS DONANTES MENORES DE EDAD
}

\section{Ma CARMEn NúÑEz MuÑIZ}

Profesora Contratada Doctora de Derecho Civil. UNED

Resumen: Con este trabajo pretendemos analizar la aptitud del menor de edad con capacidad natural para comprender el alcance del acto que se propone realizar, para prestar el consentimiento como donante de médula ósea, pues para donar otros órganos se requiere la mayoría de edad. La cuestión estriba en que la legislación de Trasplantes permite al menor consentir la extracción de médula ósea, pero previamente autorizado por sus padres, y nosotros tratamos de determinar si en caso de negativa de los representantes legales a la extracción, podrá el menor por sí solo prestar el consentimiento a la luz de las normas civiles que regulan la capacidad del menor, y de las leyes sanitarias, todas las cuales son proclives a la prestación del consentimiento por parte del interesado, si bien cuando se trata de consentir una intervención quirúrgica que redunda en su estado general de salud. También se hace referencia a la prestación del consentimiento para donar órganos e vivo un discapacitado, habida cuenta de que el Proyecto de Ley de adaptación normativa a la Convención Internacional sobre los derechos de las personas con discapacidad le permite ser donante añadiendo un nuevo párrafo al artículo 4 de la LTO, además de modificar diversas leyes sanitarias.

Palabras clave: donación de órganos, médula ósea, consentimiento informado, menor edad y emancipación, discapacidad. 
Abstract: This paper tries to analyze the capacity of minors with natural capacity to comprehend the act they are willing to complete, to give his consent as a bone marrow donor, since to donate other organs majority is required. The question lies in the Spanish Legislation of transplants, that allows the minors consent the bone marrow extraction but with a previous parental authorization. We try to explain if the legal representative denies the extraction, if the minor could by itself consent the act within the civil legislation that regulate the minors capacity, and the sanitary laws, all of them are prone to consenting the act by the concerned, although when is about to consent an operation that is in interest of its general wealth state. As well it is mention the consent to organ donation by a disable, having into account that the Proyecto de Ley de adaptación normativa a la Convencion Internacional sobre los Derechos de las personas con discapacidad, allows the donation of the minor by adding a new paragraph to the 4 precept of the LTO, as well as modifying other sanitary laws.

Key words: Organ donation, bone marrow, disable, minor and majority, consent.

Sumario: I. Requisitos para la obtención de órganos de donantes vivos: el artículo 4 de la LTO y la adición sobre consentimiento de personas con discapacidad.-II. El consentimiento del donante vivo: el supuesto del donante menor de edad.-III. La prestación del consentimiento del menor mayor de dieciséis años.-IV. Concepto de discapacidad y aptitud de la persona con discapacidad para prestar el consentimiento.-V. Los menores emancipados como donantes de órganos y de médula ósea: nuevas perspectivas.-VI. Apreciaciones conclusivas.

\section{REQUISITOS PARA LA OBTENCIÓN DE ÓRGANOS DE DONANTES VIVOS: EL ARTÍCULO 4 DE LA LTO Y LA ADICIÓN SOBRE CONSENTIMIENTO DE PERSONAS CON DISCAPACIDAD.}

El artículo 4 de la Ley 30/79, de 27 de octubre, sobre extracción y trasplantes de órganos (en adelante LTO) dispone: «la obtención de órganos procedentes de un donante vivo, para su ulterior injerto o implantación en otra persona, podrá realizarse si se cumplen los siguientes requisitos:

que el donante sea mayor de edad 
que el donante goce de plenas facultades mentales y haya sido previamente informado de las consecuencias de su decisión. Esta información se referirá a las consecuencias previsibles de orden somático, psíquico y psicológico, a las eventuales repercusiones que la donación puede tener sobre su vida personal, familiar y profesional, así como los beneficios que con el trasplante se espera haya de conseguir el receptor.

Que el donante otorgue su consentimiento de forma expresa, libre y consciente, debiendo manifestarlo, por escrito, ante la autoridad pública que reglamentariamente se determine, tras las explicaciones del médico que haya de efectuar la extracción, obligado éste a firmar también el documento de cesión del órgano. En ningún caso podrá efectuarse la extracción sin la firma previa de este documento. A los efectos establecidos en esta Ley, no podrá obtenerse ningún tipo de órganos de personas que, por deficiencias psíquicas o enfermedad mental o por cualquier otra causa, no puedan otorgar su consentimiento expreso, libre y consciente.

Que el destino del órgano extraído sea su trasplante a una persona determinada, con el propósito de mejorar su esperanza o sus condiciones de vida, garantizándose el anonimato del receptor».

Aquí debemos poner de manifiesto que con fecha 17 de diciembre de 2010 se ha publicado en el Boletín Oficial de las Cortes Generales, un proyecto de Ley de adaptación normativa a la Convención internacional sobre los derechos de las personas con discapacidad, por el que se modifican, entre otras, diversas leyes sanitarias y, concretamente, la LTO, añadiendo un apartado e) al artículo 4 anteriormente transcrito, que dispone lo siguiente: «Si el donante fuese una persona con discapacidad que cumpla los requisitos previstos en los apartados anteriores, la información y el consentimiento deberán efectuarse en formatos adecuados, siguiendo las reglas marcadas por el principio del diseño para todos, de manera que resulten accesibles y comprensibles a su tipo de discapacidad».

Nos parece oportuna la introducción de este último párrafo al artículo 4 de la LTO para despejar las dudas que pudieran suscitarse respecto de la posibilidad de que un discapacitado, dependiendo, claro está, del tipo de discapacidad y del órgano que pretenda ceder, de ser un donante de órganos vivo, cosa que hasta el momento, pues nada se decía al respecto, podía suscitar ciertos recelos, sobre todo por parte del equipo médico que debería efectuar la extracción, sobre todo habida cuenta de que el Real Decreto 426/1980, de 22 de febrero, por el que se desarrolla la Ley 30/1979, de 27 de octubre, sobre ex- 
tracción y trasplantes de órganos, exige en su artículo 2.a que el donante goce de plenas facultades mentales y de un estado de salud adecuado $^{1}$ para la extracción.

Persiste la necesaria interpretación y alcance del estado de salud adecuado, pero suponemos que eso será objeto de valoración por parte del equipo médico teniendo en cuenta la discapacidad del donante y el órgano o tejido que pretende donar. Pudiera decirse que es una especie de concepto jurídico indeterminado que habrá que analizar caso por caso.

\section{EL CONSENTIMIENTO DEL DONANTE VIVO: EL SUPUESTO DEL DONANTE MENOR DE EDAD}

A la vista del artículo 4 de la LTO, incluso teniendo en cuenta el nuevo apartado, resulta evidente la importancia que en esta materia tiene la prestación del consentimiento por parte de un donante vivo, quedando, además descartada la cesión de un órgano por un menor de edad, esté o no emancipado y por mucha capacidad natural que tenga de entender el alcance del acto que va a realizar.

De todas formas, se realza la prestación del consentimiento por el donante en la medida que el Proyecto de Ley que estudiamos modifica al respecto el apartado 5 del artículo 9 de la Ley 41/2002, de 14 de noviembre, reguladora de la autonomía del paciente y de derechos y obligaciones en materia de información y documentación clínica, en los siguientes términos:

«La prestación del consentimiento por representación será adecuada a las circunstancias y proporcionada a las necesidades que haya que atender, siempre a favor del paciente y con respecto a su dignidad personal. El paciente participará, en la medida de lo posible en la toma de decisiones a lo largo del proceso sanitario. Si el paciente es una persona con discapacidad, se le ofrecerán las medidas de apoyo pertinentes, incluida la información en formatos adecuados , siguiendo las normas marcadas por el principio del diseño para todos de manera que resulten accesibles y comprensibles a las personas con discapacidad, para favorecer que pueda prestar por sí su consentimiento».

Como puede apreciarse de la regulación transcrita, se tiende a que el propio paciente preste por sí el consentimiento, evitando en la

\footnotetext{
${ }^{1}$ La negrita es nuestra.
} 
medida de los posible, el consentimiento por representación. Cierto es que tales normas lo que contempla es la aplicación de un tratamiento o intervención quirúrgica que beneficia el estado de salud general del interesado, cosa que no ocurre con los trasplantes en que el beneficiario es un tercero, pero esto lo veremos con más detenimiento en el lugar oportuno.

Pese a la exigencia de mayoría de edad para poder ser donante de

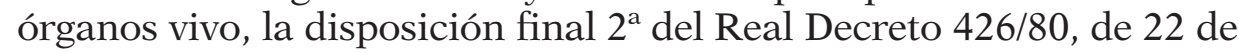
febrero, que desarrolla la Ley de 27-10-1979, establece, entre otras cosas, lo siguiente: «Dadas las características biológicas de la médula ósea, los menores de edad pueden ser donantes, previa autorización de sus padres o tutores».

La dicción de este artículo da toda la impresión de que quien debe prestar el consentimiento es el propio menor, si bien autorizado por sus padres o tutor, lo cual descartaría la donación de aquéllos que, por su corta edad carecen de capacidad natural para entender el alcance de lo que van a realizar y, por tanto, la prestación de un consentimiento libre y consciente, de ahí que algún autor ha considerado que el exclusivo consentimiento de los representantes legales conllevaba que tal acto fuese radicalmente nulo.

Con todo, el supuesto de los menores que carezcan de capacidad natural para entender el alcance del acto y su razonable imposibilidad para ser donantes de médula ósea parece confirmarlo el artículo 2.2 del Real Decreto 411/1996, de 1 de marzo que regula las actividades relativas a la utilización clínica de tejidos humanos al exigir, además del consentimiento de los padres o tutor, que el donante menor de edad sea oído conforme prevé el artículo 9.1 de la Ley Orgánica 1/1996, de 15 de enero de Protección Jurídica del Menor.

Pero ¿qué ocurre con aquellos menores que han alcanzado una edad que les permita prestar el citado consentimiento por tener una capacidad natural de comprensión de las consecuencias de su decisión; es en este caso también necesario el consentimiento de sus padres o tutor; podrán tales personas actuar incluso en contra de la voluntad de sus padres para salvar la vida de un hermano, consentimiento que los padres niegan ante el temor de perder a los dos hijos? Pues qué duda cabe que la extracción de médula ósea conlleva también sus riesgos. Por otro lado, si el menor se niega a someterse a la extracción ¿pueden los padres imponerla en contra de su voluntad?

En las siguientes líneas nos centraremos en la donación de médula ósea por parte de menores, sin dejar de referirnos a los disca- 
pacitados a la vista del Proyecto de Ley anteriormente citado, pues pese a que un mayor de edad, por ejemplo de 18 ó 19 años es un joven, no plantea ningún problema la prestación de su consentimiento para la donación, no sólo de médula ósea, sino de ningún tipo de órganos, siempre que sean compatibles con la vida del donante, claro y, según el artículo 2.b del Real Decreto 426/1980, de 22 de febrero, por el que se desarrolla la Ley 30/1979, de 27 de octubre, sobre extracción y trasplante de órganos, que no disminuya gravemente su capacidad funcional.

Cosa distinta ocurre sobre todo con los adolescentes, centrándonos fundamentalmente en el menor mayor de 16 años, sin perjuicio de que hagamos alguna referencia a los menores a partir de los 12 años habida cuenta de que el Código civil impone en alguno de sus preceptos la necesidad de que el menor mayor de 12 años sea oído antes de adoptar decisiones que les afecten, e incluso antes de esa edad si tuvieran suficiente juicio. De la misma manera la Ley 41/2002, de 14 de noviembre reguladora de la Autonomía del paciente y derechos y obligaciones en materia de información y documentación clínica, establece en su artículo 9.3.c que el consentimiento se prestará por representación cuando el menor de edad no sea capaz intelectual ni emocionalmente de comprender el alcance de la intervención, pero tras haber escuchado su opinión si tiene 12 años cumplidos.

\section{LA PRESTACIÓN DEL CONSENTIMIENTO DEL MENOR MAYOR DE DIECISEIS AÑOS}

En este caso que nos ocupa, el artículo 9.3.c de la Ley de Autonomía del paciente dispone que «cuando se trate de menores no incapaces ni incapacitados, pero emancipados o con 16 años cumplidos no cabe prestar el consentimiento por representación».

Dicho apartado está reconociendo de manera clara, que en este supuesto son los menores los que deben consentir ${ }^{2}$, sin necesidad de que intervengan sus representantes legales, no sólo prestando su consentimiento, cosa que el precepto parece rechazar, sino también asesorando al menor o dando su opinión ${ }^{3}$, excepto en casos de grave

\footnotetext{
${ }^{2}$ Cfr. Ruiz Jiménez, J. «La Capacidad del menor en el ámbito sanitario», en La capacidad de obrar del menor: nuevas perspectivas jurídicas, ed. Exlibris Ediciones, 2009, pág. 84 .

${ }^{3}$ En este mismo sentido ParRa LuCÁn, M.A., «la capacidad del paciente para prestar válido consentimiento informado». El confuso panorama legislativo español»,
} 
riesgo, a juicio del facultativo, en que los padres serán escuchados y su opinión será tenida en cuenta.

Sin embargo, se da la circunstancia de que el mismo apartado del artículo que comentamos dispone que «cuando el paciente menor de edad no sea capaz intelectual ni emocionalmente de comprender el alcance de la intervención, el consentimiento se otorgará por representación». De esto podría deducirse a sensu contrario que si el menor, antes de los dieciséis años tiene suficiente capacidad natural para comprender el alcance de la intervención, es él quien presta el consentimiento ${ }^{4}$.

En esta misma línea parece moverse el Proyecto de Ley al que nos hemos venido refiriendo relativo a las personas con discapacidad al modificar el apartado 5 del artículo en estudio. Quedaría de la siguiente manera: «La prestación del consentimiento por representación será adecuada a las circunstancias y proporcionada a las necesidades que haya que atender, siempre a favor del paciente y con respeto a su dignidad personal. El paciente participará en la medida de lo posible en la toma de decisiones a lo largo del proceso sanitario. Si el paciente es una persona con discapacidad, se le ofrecerán las medidas de apoyo pertinentes, incluida la información en formatos adecuados, siguiendo las reglas marcadas por el principio del diseño para todos de manera que resulten accesibles y comprensibles a las personas con discapacidad, para favorecer que pueda prestar por sí su consentimiento» ${ }^{5}$.

Como puede observarse, también esta norma trata de favorecer que sea el propio discapacitado quien preste el consentimiento al tratamiento o intervención que trata de aplicársele, evidentemente con las limitaciones que su discapacidad le imponga.

\footnotetext{
Aranzadi Civil, $\mathrm{n}^{\circ}$ 2, Pamplona, 2003, pág. 6, opina que conforme a la Ley, si el menor está emancipado o ha cumplido 16 años no cabe prestar el consentimiento por representación. En principio el representante legal consiente por el menor cuando no esté emancipado o tenga menos de 16 años. Pero, además, y aunque la redacción es confusa, el artículo 9.3 c, permite entender que antes de los 16 años, la intervención de los padres como representantes sólo es posible si el menor no puede entender el alcance del acto. De esta manera, quedan fuera del ámbito de la actuación por representación las decisiones relativas a los menores que, no teniendo cumplidos 16 años, tengan sin embargo, madurez suficiente para comprender el alcance de la intervención.

${ }^{4}$ Cfr. Parra Lucan, M. A., "La capacidad del paciente para otorgar válido consentimiento informado. El confuso panorama legislativo español», Aranzadi Civil, n $^{\circ} 2$, 2003, pág. 6.

${ }^{5}$ Véase en este sentido el artículo 2.1 de la Convención sobre los derechos de las personas con discapacidad.
} 


\section{CONCEPTO DE DISCAPACIDAD Y APTITUD DE LA PERSONA CON DISCAPACIDAD PARA PRESTAR EL CONSENTIMIENTO}

Llegados a este punto, tal vez resulte clarificador determinar quienes se consideran personas con discapacidad ${ }^{6}$. El apartado 2 del artículo 1 de la Ley 51/2003, de 2 de diciembre, de igualdad de oportunidades, no discriminación y accesibilidad de las personas con discapacidad, resultaría modificado por el Proyecto de Ley de adaptación normativa a la Convención internacional sobre los derechos de las personas con discapacidad, tantas veces citado, al disponer lo siguiente: «Son personas con discapacidad aquellas que presenten deficiencias físicas, mentales, intelectuales o sensoriales a largo plazo que, al interactuar con diversas barreras, puedan impedir su participación plena y efectiva en la sociedad, en igualdad de condiciones con los demás», concepto que coincide exactamente con el proporcionado por la Convención sobre los derechos de las personas con discapacidad, hecho en Nueva York el 13 de diciembre de 2006, en su artículo 1.2. De la dicción de esta norma resulta fácil colegir que un discapacitado mental o intelectual, no podrá, al menos en principio, pues en todo caso dependerá del grado de discapacidad y comprensión que la misma le permita, amén de lo que deba consentir, prestar por sí mismo el consentimiento, debiendo hacerlo por representación. Esto en el ámbito sanitario en general; es decir, cuando el beneficiario del tratamiento o intervención sea el propio discapacitado pero, ¿qué sucede cuando se trate de donar un órgano que en nada beneficia al donante, sino a un tercero? Como en este trabajo nos hemos centrado más en la donación de médula ósea que por sus características se permite que los menores puedan cederla, a diferencia de lo que ocurre con otros órganos para los cuales se exige la mayoría de edad, ¿podrían los padres de un discapacitado mental suplir su consentimiento para la donación en beneficio de otro hijo? Parece evidente, a la luz del artículo 4 LTO que no puede donar órganos, como por ejemplo, un riñón, pero ¿y la médula? En nuestra opinión, tampoco $^{7}$, pues la disposición final $2^{\mathrm{a}}$ del Real Decreto que desarrolla la

${ }^{6}$ Para un concepto de discapacidad, véase MoRetón SANZ, «Protección civil de la discapacidad: Patrimonio protegido y obras de accesibilidad en la Propiedad Horizontal», $R C D I, \mathrm{n}^{\circ}$ 687, 2005, págs. 62 a 64; «De la minusvalía a la discapacidad y dependencia: pasarelas y asimilaciones legales», Revista Universitaria de Ciencias del trabajo, Valladolid-Lex Nova, $\mathrm{n}^{\circ} 8,2009$, donde se establece la distinción entre discapacidad y minusvalía, pág. 90.

${ }^{7}$ En este sentido, cfr. LÓPEZ FRÍAs, «El ejercicio de los derechos personalísimos de los enfermos psíquicos», $R D P$, abril, 1999, págs. 304 y 305. Se manifiesta de forma contundente al decir: «Nos hallamos ante otro acto personalísimo porque la voluntad 
LTO, exige el consentimiento del menor, si bien autorizado por sus padres, pero en ninguna norma se encuentra referencia a la sustitución del consentimiento del donante de órganos o tejidos. En este sentido debemos traer a colación lo dispuesto en la letra n) del Preámbulo de la Convención sobre los derechos de las personas con discapacidad al disponer que hay que reconocer la importancia que para las personas con discapacidad reviste su autonomía e independencia individual, incluida la libertad de tomar sus propias decisiones. Libertad e independencia que reitera en el artículo 3. Por su parte el artículo 25.d) dispone que se exigirá a los profesionales de la salud que presten a las personas con discapacidad atención de la misma calidad que a las demás personas sobre la base de un consentimiento libre e informado ${ }^{8}$. De lo cual se deduce que el consentimiento debe prestarlo el interesado.

En este sentido Romero Pareja, A. ${ }^{9}$ al referirse a las condiciones en las que un donante debe prestar su consentimiento a la extracción, exige, entre otras cosas, Autonomía, entendiendo por tal el respeto al individuo como persona; esto es, respeto a las decisiones que haya tomado. En los trasplantes, el donante tiene que ser capaz de decidir por sí mismo y sin ninguna presión, lo que sólo es posible en las siguientes circunstancias:

- Proporcionando información detallada sobre los beneficios posibles del trasplante y los riesgos de las complicaciones (incluyendo la posible mortalidad para el donante y/o receptor, considerando también el retrasplante por fallo del órgano o de la aceptación del mismo).

Prestación del consentimiento informado por el donante: el donante con información adecuada es el único que puede decidir en un acto libre.

Someter al donante a una evaluación psicológica, si fuera preciso.

No se permite coacción ni se aceptará la donación de urgencia; en cuyo caso no habría condiciones para decidir correctamente.

Si tenemos en cuenta estas exigencias, hemos de llegar a la conclusión de que siempre, tratándose de un donante vivo, es el propio

de donar es estricta y exclusivamente personal. Si el incapaz no tiene aptitud para conocer y querer la donación de alguno de sus órganos, no podrá nunca llevarse a cabo porque no cabe sustitución de voluntad por el representante legal».

${ }^{8}$ La negrita es nuestra.

9 "Consentimiento informado ante la donación de órganos», Diario La Ley, 11 de enero de 2011, pág. 5. 
interesado el que debe prestar el consentimiento ${ }^{10}$. Claro que cuando se trata este tema se refieren, tanto las normas reguladoras como la doctrina, a trasplantes de órganos y queda la duda de si en esta expresión genérica se incluye también la donación de médula ósea, o si por el contrario, dadas sus características es susceptible de un tratamiento distinto; más flexible que, por ejemplo, la donación de un riñón o un pulmón.

De hecho el Real Decreto que desarrolla la LTO, permite a los menores donar médula ósea, cosa que no se permite con otros órganos. No obstante, de su redacción se desprende claramente que es el propio menor el que debe prestar el consentimiento, aunque autorizado por sus padres, en cuyo caso, al menos en nuestra opinión, quedaría descartada la prestación del consentimiento por representación de un incapaz, pues como se verá, la donación de este tejido conlleva riesgos para el donante.

Retomando el tema de la capacidad de los menores para prestar el consentimiento por sí mismos, algún autor como BELTRÁN AGUIRRE ${ }^{11}$, basándose en la doctrina del menor maduro en el ámbito sanitario, elaborada en Estados Unidos a partir de 1970 que se basa en el principio de que los derechos de la personalidad pueden y deben ser ejercidos autónomamente por la persona desde el momento en el que pueden disfrutar conscientemente de ellos, esto es, cuando tengan juicio natural suficiente, circunstancia que en la mayoría de las personas sucede bastante antes de los 18 años, sostiene que entre los derechos de la personalidad se encuentra todo lo relativo a la salud de las personas, y alega una serie de normas de nuestra legislación civil que avalan su teoría de atender más que a la edad, a la capacidad natural de comprensión del menor. Así el artículo 154 del Código civil dispone que los hijos no emancipados están bajo la potestad del padre y de la madre, y si los hijos tuvieren suficiente juicio deberán ser oídos antes de adoptar decisiones que les afecten. Por otro lado, el artículo 162.1 del mismo Cuerpo legal exceptúa de la necesidad de consenso y aceptación de los padres los actos relativos a derechos de la personalidad (como la salud, vida, integridad física, etc.), que el

${ }^{10}$ Cfr. LÓPEZ FRÍAs, ob. cit., págs. 304 y ss.

11 "Anticoncepción, contracepción de emergencia y minoría de edad», Revista Aranzadi Doctrinal, $\mathrm{n}^{\circ} 11,2009$, págs. 1-3. E n cuanto a la capacidad para prestar el consentimiento Romero PAREJA, A., "Consentimiento informado ante la donación de órganos para trasplante», Diario La Ley, no 7544, 11 de enero de 2011, pág. 26, dice que debe ser la suficiente para comprender la situación en la que consiente el paciente. 
hijo de acuerdo con las leyes y sus condiciones de madurez, pueda realizar por sí mismo.

Por su parte, la Ley Orgánica 1/1982, de 5 de mayo, de Protección civil del Derecho al Honor, Intimidad Personal y Familiar y Propia Imagen, dispone en su artículo 3 que «el consentimiento de los menores e incapaces deberá prestarse por ellos mismos si sus condiciones de madurez lo permiten, de acuerdo con la legislación civil».

No debe obviarse aquí la Ley Orgánica 1/1996, de 15 de enero, de Protección Jurídica del Menor, al declarar en su preámbulo que el Ordenamiento jurídico y la ley en particular, va reflejando progresivamente una concepción de los menores como sujetos activos, participativos y creativos con capacidad de modificar su propio medio personal y social; de participar en la búsqueda y satisfacción de sus necesidades y en la satisfacción de las necesidades de los demás, y en su artículo 2.2 establece que las limitaciones a la capacidad de obrar de los menores se interpretarán de forma restrictiva ${ }^{12}$.

Y, finalmente, el Convenio de Oviedo en su artículo 6.2 establece que la opinión del menor será tomada en consideración como un factor que será tanto más determinante en función de su edad y su grado de madurez.

Pese a ello, no hay que olvidar que las citadas leyes que tienen en cuenta el consentimiento del menor con suficiente juicio se refieren al mismo cuando él sea el paciente y la intervención o tratamiento que debe consentir redunde en su utilidad y en su estado general de salud.

Cosa distinta es la de un donante de órganos, en este caso de médula ósea, en que el donante, no obtiene ningún beneficio con la cesión de uno de sus órganos o tejidos humanos, como la médula, sino que lo hace a favor de un tercero y a costa de soportar unas, por lo menos, incomodidades e incluso de correr unos riesgos, como la anestesia o incluso sufrir determinadas secuelas a consecuencia del número de punciones que deben practicarse para la extracción de la médula, entre trescientas y cuatrocientas y, por lo tanto gravemente perjudicial para su integridad ${ }^{13}$.

Refiriéndose a la obtención de órganos para trasplante de un donante vivo, pero evidentemente aplicable también a la obtención de

12 Sobre esta Ley, véase nuestro trabajo, «Algunas consideraciones sobre la Ley Orgánica 1/1996 de 15 de enero, de protección jurídica del menor», Revista: La Ley. 1996, vol. 5. págs. 1483-1490.

${ }^{13}$ Cfr. Angoitia Gorostiaga, V. Extracción y trasplante de órganos y tejidos humanos. Problemática jurídica, ed. Marcial Pons, Madrid, 1996, pág. 338. 
tejidos, como la médula ósea, la Directiva 2010/53/UE, de 7 de julio, sobre normas de calidad y seguridad de los órganos humanos destinados al trasplante, destaca que los donantes vivos corren riesgos relacionados tanto con las pruebas para determinar su idoneidad (pues se exige que el donante vivo deba ser evaluado adecuadamente para determinar su idoneidad para la donación y minimizar el riesgo de transmisión de enfermedades al receptor) como con el propio procedimiento de obtención del órgano, pudiendo presentarse complicaciones médicas, quirúrgicas, sociales, financieras o psicológicas ${ }^{14}$.

En este sentido cabe destacar la SAP de 4 de abril de 1995 en la que una donante de médula ósea como consecuencia de las punciones, un hematoma se desplazó afectando el nervio cruzal izquierdo, produciendo una parexia importante con pérdida axonal, lo que le dificulta para la deambulación, sin concretarse en parálisis, obstaculizando movimientos como los de subida de escaleras. Con lo cual el riesgo de la intervención es evidente, lo que nos lleva a plantearnos si en este caso, y pese a la dicción de la Ley de Autonomía del paciente, menores, pese a tener más de 16 años necesitan el consentimiento de sus representantes legales para este tipo de intervención.

Así el Real Decreto 411/1996, de 1 de marzo, que regula las actividades relativas a la utilización clínica de tejidos humanos, dispone en su artículo 7.2 que los menores de edad pueden ser donantes de médula ósea exclusivamente para las situaciones en que exista relación genética entre donante y receptor y siempre ${ }^{15}$ con previa autorización de sus padres o tutores, si bien en el siguiente apartado dispone que en estos casos el menor de edad deberá ser oído conforme prevé el artículo 9.1 de la Ley Orgánica 1/1996, de 15 de enero de Protección Jurídica del Menor.

${ }^{14}$ Debemos poner de manifiesto que esta Directiva pretende uniformizar las normas de los Estados miembros en cuanto a observar unas garantías en la obtención, conservación, traslado entre los distintos países de la Unión e incluso con terceros, de órganos para trasplante en un intento de minimizar los riesgos de infección o reacciones adversas del receptor y también del donante cuando éste es una persona viva. Para nuestro trabajo esto presenta escaso interés puesto que se exige que donante y receptor estén emparentados genéticamente, con lo que no es necesario efectuar ningún traslado. De hecho se refiere más que a tejidos, pese a contener alguna referencia a los mismos, a órganos a los que define en el artículo $3 \mathrm{~h}$ como parte diferenciada del cuerpo humano formada por diferentes tejidos, que mantiene su estructura, vascularización y capacidad para desarrollar funciones fisiológicas con un nivel de autonomía importante. Se considera, asimismo, órgano la parte de éste cuya función sea la de ser utilizada en el cuerpo humano con la misma finalidad que el órgano completo, manteniendo los requisitos de estructura y vascularización.

${ }^{15}$ La negrita es nuestra. 
La redacción de este precepto y, en particular, el uso de la palabra «siempre», parece dar a entender que en todo caso cualquier menor, con independencia de su edad va a necesitar el consentimiento de sus representantes legales. El hecho de que se refiera exclusivamente al tutor parece dejar fuera a los emancipados, pues éstos no están sometidos a tutela, sino a curatela, a falta de padres, naturalmente y, dada la omisión del curador, parece que se impone analizar si un menor emancipado puede prescindir del consentimiento de sus padres o curador para ser donante de médula ósea, por ejemplo, a favor de un hermano.

\section{LOS MENORES EMANCIPADOS COMO DONANTES DE ÓRGANOS Y DE MÉDULA ÓSEA: NUEVAS PERSPECTIVAS}

En este caso parece que las normas que exigen mayoría de edad para poder ser donante de órganos o las que imponen el previo consentimiento de los representantes legales del menor para ser donante de médula deben ser interpretadas a la luz del artículo 323 del Código civil que dispone que el emancipado puede regir su persona y bienes como si fuera mayor, salvo los actos enumerados en el propio precepto para la realización de los cuales necesita el complemento de capacidad por parte de sus padres o del curador, y entre esos actos no se encuentra precisamente la disposición de órganos o tejidos de su propio cuerpo; se refiere exclusivamente a actos de carácter patrimonial.

Ante esto, tal vez cabría la posibilidad de defender la postura de que el emancipado puede consentir por sí mismo la extracción de algún tejido u órgano de su cuerpo para ser trasplantado a otra persona como si fuera mayor. De hecho, no faltan autores que sostienen que la equiparación del menor emancipado al mayor de edad es total en el ámbito personal ${ }^{16}$.

Tal planteamiento vendría avalado por la necesidad de interpretar restrictivamente las limitaciones a la capacidad de obrar ${ }^{17}$.

No obstante, los anteriores argumentos no son suficientes según Angoitia Gorostiaga ${ }^{18}$, para fundamentar la admisión de que los

${ }^{16}$ Cfr. Urbano Gómez, S., «Minoría de edad penal. Capacidad para consentir: especial consideración a las intervenciones médicas», Actualidad Jurídica Aranzadi, ${ }^{\circ}$ 339, 1998, pág. 5.

${ }^{17}$ Cfr. Angoitia Gorostiaga, V, ob. cit., pág. 343.

${ }^{18}$ Ob. cit., pág. 343. 
emancipados consientan por sí mismos la extracción de elementos o sustancias de su cuerpo, ni siquiera la extracción de la médula ósea cuyo destino es una persona emparentada genéticamente con el menor emancipado, pues ni la habilitación general del artículo 323 del Código civil han de interpretarse en el sentido de que un menor emancipado pueda consentir válidamente la extracción de un órgano o tejido de su cuerpo.

Opina el citado autor que la mayoría de edad debe entenderse aquí en sentido literal, dada la excepcional trascendencia de este tipo de donación.

Nosotros no podemos compartir esta opinión, pues pensamos que entre un joven de 17 años, menor de edad, emancipado o no, no hay tanta diferencia con otro de 18, que ya es mayor. El tema, a nuestro entender debe depender más de la capacidad natural del menor que de la edad, pues unas personas maduran antes que otras, y algunos tienen a muy corta edad una capacidad de comprensión muy superior a la de otros de edad superior. De hecho el artículo 6 del Convenio de Oviedo no establece la línea divisoria para poder prestar un consentimiento atendiendo a la edad, sino más bien a la capacidad natural ${ }^{19}$.

Como pone de relieve MARTínez-Pereda RodríGUEz ${ }^{20}$, en relación con las condiciones de madurez se hallan los actos relativos a los derechos de la personalidad, a los que específicamente se refiere el artículo 162.1 del Código civil, al exceptuar la representación legal de los hijos menores o emancipados por los padres que ostenten la patria potestad, «los actos relativos a derechos de la personalidad». Y la Ley Orgánica 1/1982, de 5 de mayo, en su artículo 3.1 prevé que «el consentimiento de los menores o incapaces deberá prestarse por ellos mismos si sus condiciones de madurez lo permiten, de acuerdo con la legislación civil» ${ }^{21}$.

En este punto no debemos dejar de tener en cuenta la Ley Orgánica $2 / 2010$, de 3 de marzo, sobre salud sexual y reproductiva y de la

${ }^{19}$ Dice así: art 6.1 «A reserva de lo dispuesto en los artículos 17 y 20, sólo podrá efectuarse una intervención a una persona que no tenga capacidad para expresar su consentimiento cuando redunde en su beneficio directo.

2. Cuando, según la ley, un menor no tenga capacidad para expresar su consentimiento para una intervención, ésta sólo podrá afectarse con autorización de su representante, de una autoridad o una persona o institución designada por la ley. La opinión del menor será tomada en consideración en función de su edad y su grado de madurez».

${ }^{20}$ Ob. cit., pág. 4.

${ }^{21}$ Cfr. Martínez-Pereda Rodríguez, ob. cit., pág. 4. 
interrupción voluntaria del embarazo, la cual en su artículo 13. 4, dispone lo siguiente: «en el caso de las mujeres de 16 y 17 años, el consentimiento para la interrupción voluntaria del embarazo les corresponde exclusivamente a ellas de acuerdo con el régimen general aplicable a las mujeres mayores de edad».

Esta Ley está reconociendo de manera expresa la capacidad de las menores de 16 y 17 años de consentir ellas solas la interrupción voluntaria del embarazo, equiparándolas a las mujeres mayores de edad, y ello sin necesidad de que estén emancipadas, pues en caso de que así fuera, el artículo 323 del Código civil dispone que la emancipación habilita al menor para regir su persona y bienes como si fuera mayor, pero este no es el supuesto de la Ley cuyo precepto comentamos. Y se supone que también la interrupción de un embarazo puede conllevar ciertos riesgos, como secuelas psicológicas, imposibilidad de volver a concebir, etc. Si esto es así en esta Ley, no entendemos porque un joven de 16 ó 17 años, máxime si está emancipado, no puede consentir por sí mismo la extracción de médula ósea, pues en definitiva se trata de un tejido regenerable.

Llegados a este punto tal vez convenga determinar qué se entiende por tejido humano. Según el artículo 2.1 del Real Decreto 411/1996 se entiende por tal «todas las partes constituyentes del cuerpo humano, incluyendo los residuos quirúrgicos y las células. También se incluyen los productos que incorporen tejidos o células de origen humano o deriven de ellos».

En contra de la postura arriba defendida se pronuncia ANGOITIA GorostiagA $^{22}$ por entender que el menor de edad en ningún caso puede consentir por sí mismo la extracción de un órgano o tejido de su cuerpo, incluso cuando su edad, cualidades personales o emancipación, le hagan aparecer como persona dotada de suficiente madurez o capacidad de comprensión, en función de las cualificadas garantías y requisitos de los que la donación en vida adornan nuestro sistema; cree que tal previsión contemplada en la Ley 1/1982 ha de extenderse en el ámbito de la cirugía sustitutiva, a todo menor de edad, independientemente de su capacidad de discernimiento.

Nosotros, sin embargo, consideramos que, precisamente es en función de esas garantías lo que debe permitir que los menores con un cierto grado de madurez puedan prescindir del consentimiento de

${ }^{22}$ Ob. cit., pág. 349. 
sus representantes legales, pues como ya se ha puesto de relieve más arriba, la Ley exige que el consentimiento sea prestado tras una amplia información por parte de los facultativos y de una autoridad pública que, según el artículo 4 del RD de 22 de febrero, será el juez encargado del Registro civil de la localidad de que se trate(quien, junto con lo médicos asistentes, podrán asegurarse del grado de madurez y comprensión del menor para prestar el consentimiento) tras las explicaciones del médico que haya de efectuar la extracción y en presencia del facultativo a que se refiere el artículo anterior y la persona a quien corresponde dar la conformidad para la extracción. El documento de cesión será firmado por el interesado y por los demás asistentes, pudiendo cualquiera de ellos oponerse a la extracción si albergan duda sobre la manifestación del consentimiento del donante en forma expresa, libre, consciente y desinteresada; además, entre la firma de dicho documento y la extracción del órgano deben transcurrir, al menos, 24 horas. El donante puede revocar su consentimiento en cualquier momento antes de la intervención, sin sujeción a formalidad alguna.

Como puede observarse, las garantías exigidas por la ley para la prestación del consentimiento de un donante de órganos vivo, y para la extracción del órgano, al que puede negarse en cualquier momento, aún después de haber firmado el documento de autorización, unido al plazo de 24 horas que debe transcurrir entre la prestación del consentimiento y la extracción del órgano para que el donante medite sobre su decisión, pudiendo revocarla, es lo que a nuestro juicio nos permite defender la postura de la prestación del consentimiento del menor maduro por sí solo, sin necesidad del consentimiento paterno, con independencia de que éste también pueda concurrir si ambos están de acuerdo, pero en caso de discrepancia, debe prevalecer la voluntad del menor y permitirle autorizar que se le practique la extracción de la médula.

Aunque no creemos que se trate de un supuesto muy frecuente en la práctica, sino todo lo contrario, imaginemos el caso de unos padres con dos hijos, uno de los cuales padece leucemia y su salvación depende de un trasplante de médula ósea. Su hermano de 16 años quiere donarle la suya y salvarle, pero los padres se oponen por los riesgos que pueda correr en el proceso de extracción y ante el temor de perder a los dos hijos. ¿Debe este joven con plena capacidad natural de entender las consecuencias del acto que se propone realizar, quedarse impasible viendo como se muere su hermano por el temor de sus padres y su negativa a prestar el consentimiento? ¿Qué dife- 
rencia existe en este $\operatorname{caso}^{23} \mathrm{y}$ el de una menor de 16 ó 17 años que decide interrumpir su embarazo, para lo cual, como ya se ha visto, no es necesario el consentimiento de sus representantes legales?, pues tampoco sería la primera que fallece a causa de esta intervención.

Según nuestro parecer, estas exigencias deberían ser sometidas a revisión y no interpretarlas de forma tan literal, sino con flexibilidad, atendiendo más a la capacidad natural del menor que al rígido criterio de una edad determinada, pues hay suficientes normas en la legislación civil, como se ha visto, que avalan el tener en cuenta la capacidad natural de entender y comprender de las personas que aún no han alcanzado la mayoría de edad.

Tras lo dicho hasta el momento, qué duda cabe de que los padres o tutores de un menor, bajo ningún concepto pueden obligarle a efectuar la donación si éste se niega, pues su consentimiento es requisito sine qua non para que la extracción se efectúe, y ello incluso tratándose de niños de 12 años o incluso menores, si en opinión del juez que debe oírle, tuvieran suficiente juicio. Si manifiestan una voluntad contraria, no podrá llevarse a cabo la extracción ${ }^{24}$.

\section{APRECIACIONES CONCLUSIVAS}

Tras lo visto, debemos concluir en que existe un dispar tratamiento de la prestación del consentimiento en las distintas leyes que lo regulan, sanitarias y civiles por un lado e incluso penales ${ }^{25}$, y de trasplantes, por otro, pues las primeras parecen más proclives a admitir el consentimiento atendiendo a la capacidad natural de la persona y su capacidad de comprensión más que a la edad del paciente, mientras que las segundas exigen una edad, mayoría cuando se trata

${ }^{23}$ Que insistimos, no creemos que se produzca en la práctica, pues lo habitual es que los padres de un hijo con una enfermedad para cuya curación necesita el trasplante de tejidos de una persona compatible genéticamente, lo que suelen hacer es tener otro para salvar al enfermo, pero pudiera existir, pues tampoco son raros los casos de fallecimientos debido a la anestesia.

${ }^{24}$ Cfr. Angoitia Gorostiaga, ob. cit., pág. 348.

${ }^{25}$ De hecho se ha llegado a afirmar que el Derecho penal se apoya más en el discernimiento del que presta el consentimiento que en la capacidad civil de obrar. Vid. Urbano Gómez, ob. cit., pág. 3. Quintero Olivares, G., "Consentimiento en derecho penal español. En especial referencia a las infracciones», Cuadernos del CGPJ, 1993; BuENo ARÚs, F., «Límites del consentimiento en la disposición del propio cuerpo desde la perspectiva del derecho penal», PJ, 1985; DE LA Gándara VALLEJo, Consentimiento, bien jurídico e imputación objetiva, ed. Colex, Madrid, 1995, pág. 114. 
de cesión de órganos, salvo la donación de médula ósea, pero exigiendo siempre la previa autorización de los representantes legales del donante, con independencia de la madurez del menor. A primera vista esta distinta regulación no parece carecer de sentido, toda vez que un paciente que debe consentir una intervención, lo hace en aras de su salud y general bienestar, mientras que éste no es el caso de un donante de órganos vivo, consiente una lesión en su cuerpo sano que, evidentemente puede tener unas consecuencias negativas en su organismo o ciertas limitaciones en su vida diaria, si bien ello se admite para, de forma altruista y desinteresada, salvar o mejorar las condiciones de vida de otra persona, por eso la prestación del consentimiento para este tipo de intervenciones se rodea de especiales garantías y requisitos con el fin de asegurarse de que el donante actúa consciente y libremente.

De todas formas, y centrándonos en la donación de médula ósea, nos parece que la capacidad natural del donante no debe dejarse de lado que, por cierto, no se deja, pero se exige siempre el consentimiento de los padres o tutor, curador si está emancipado, sobre todo cuando se trate de menores de cierta edad, pongamos por caso, 16 ó 17 años cuya madurez puede permitirle comprender perfectamente el alcance del acto de que va a realizar, las secuelas que como consecuencia de la extracción puede padecer y los beneficios que, como consecuencia de la donación va a experimentar el receptor. En el hipotético caso de que los padres se negaran a prestar el consentimiento en contra de la voluntad clara y consciente del joven, creemos que su solo consentimiento debería ser suficiente para proceder a la donación, y ello por las razones ya apuntadas a lo largo del trabajo y que, evidentemente, no vamos a reiterar. 